\title{
Sex Differences in Salivary and Serum Cortisol Values Among Nurses and Correlation with Work Stress
}

\author{
Blertina Dyrmishi', Taulant Olldashi ${ }^{2}$, Agron Ylli ${ }^{3}$ \\ ${ }^{1}$ Endocrinologist, Hygeia Hospital Tirana, Albania \\ ${ }^{2}$ Surgeon, UHC "Mother Theresa", Tirana, Albania \\ ${ }^{3}$ Head of Endocrinology Department, UHC "Mother Theresa", Tirana, Albania
}

\begin{abstract}
Aim: To see the difference between salivary cortisol values, correlation with the work stress, and the difference between salivary and cortisol values related to sex. Methods: The salivary and serum cortisol values were analyzed in two groups of nurses, six nurses in the Emergency Department and six nurses in the Pathology Department at our hospital, three females and three males for each group. The samples were taken before beginning the work and after finishing the work. Results: Mean serum and salivary cortisol values in the morning (08:00 AM) and at the end of the work (04:00 PM), were higher in Emergency Department compare to the mean salivary and serum values of cortisol in the Pathology Department. The salivary and serum cortisol values were higher in males compare to females, but are not statistically significant. Conclusions: Since the work stress is higher in the Emergency Department, even the results of the salivary cortisol values were higher in the nurses of the Emergency Department compared to the nurses of Pathology Department and there existed a correlation between salivary and serum values, but we needed a bigger group of study to have more trustful conclusions.
\end{abstract}

Keywords: salivary cortisol, serum cortisol, correlation, work stress

\section{Introduction}

Cortisol is a major glucocorticoid produced in the adrenal cortex and used in studies of the pituitary adrenal axis function. More than $90 \%$ of cortisol is bound to serum proteins [1]. The measuring of cortisol is performed in blood or urine, but in the last years the measuring of the salivary cortisol is also used in the clinical practice [2]-[5]. The collection of the sample in the saliva can be done by the individuals themselves, whom are being analyzed, respecting some simple instructions. It is a non-invasive, painless and stress-free procedure [6]. Salivary cortisol levels are relatively resistant to degradation from enzymes or freezethaw cycles [7].

\section{Methods}

The salivary and serum cortisol values were analyzed in two groups of nurses, six nurses working in the Emergency Department and six nurses working in the Pathology Department at our hospital, three females and three males for each group (total six females and six males). All the participants in the study were informed about the study protocol and its aim. They were in a young age, without any know acute or chronic diseases, norm weight. The participants were not taking any treatment with substituting medicine or medicines which interfered with the cortisol metabolism. They didn't consume more than a glass of wine or its equivalents per day, they didn't smoke, the coffee consumers didn't use more than two cups of coffee per day. All the participants filled questioners, which was prepared and approved before. The day of the blood and saliva samples collection, anthropometric measurements, blood pressure, heart rate and body temperature were measured. The subjects shouldn't have passed a febrile condition or be in such a condition at least two weeks before the collection of the blood and saliva samples.

All the subjects followed the rules for the collection of the saliva. The saliva was collected by the participants in the study themselves. Before the collection of the saliva sample, the participants should respect some rules:

- The use of the alcohol was forbidden for 12 hours until the collection of the saliva.

- The subjects must have been not eaten for at least one hour before the collection of the saliva sample.

- The use of the toothbrush was not allowed for at least 4560 minutes before the collection of the saliva sample.

- The use of the sweet and caffeine-containing beverages, coffee and milk products were forbidden for at least 20 before the collection of the saliva sample.

- At first the mouth was rinsed with water and after 10 minutes the saliva sample was collected.

The samples of saliva and serum were collected in the morning at 8:00 AM and in the afternoon at 4:00 PM (before work and after work).

- At the same time of the collection of the saliva samples, there were also collected the blood samples for measuring the serum cortisol. After the collection of the saliva, the samples were stored in $4^{\circ}$ Celsius for eight hours and then they were kept frozen in $-20^{\circ}$ Celsius until the moment of the analysis and then they were centrifuged for 10 minutes in $3000 \mathrm{rpm}$.

- The samples for the serum cortisol were obtained from the antecubital vein. The samples were stored in room 


\section{International Journal of Science and Research (IJSR) \\ ISSN (Online): 2319-7064 \\ Index Copernicus Value (2013): 6.14 | Impact Factor (2014): 5.611}

temperature for 20 minutes, and then they were centrifuged for 5 minutes in $3000 \mathrm{rpm}$ and were kept in $20^{\circ}$ Celsius until the moment of the analysis.

\section{Materials and Methods}

12 healthy nurses ( 6 males and 6 females), ages from 22-30 years old, were included in the study. The blood and saliva samples were collected in the morning at 8:00 AM and in the afternoon at 4:00 PM after work. All the participants in the study respected the rules of saliva samples collection. 6 nurses ( 3 females and 3 males) worked at emergency department and 6 nurses ( 3 females and 3 males) worked at pathology department.

\subsection{Laboratory Analyses}

Serum cortisol was measured by RIA CT AcM and salivary cortisol was determined by Salivary Cortisol ELISA kit.

\subsection{Statistical Analyses}

The data were presented as mean (SD). The relation between variables was expressed as correlation coefficients Pearson's coefficients. P-level $<0.05$ was considered as statistically significant.

\section{Results}

Mean serum cortisol values in the Emergency Department in the morning (8:00 AM) were $188 \pm 30 \mathrm{ng} / \mathrm{ml}$ (normal range 55-230) and mean salivary cortisol values $3.1 \pm 1.4 \mu \mathrm{g} / \mathrm{dl}$ (normal range 1-11.3) and at the end of work (4:00 PM) the values were: serum cortisol values $130 \pm 28 \mathrm{ng} / \mathrm{ml}$ (normal range 28-140) and salivary cortisol values $1.87 \pm 0.5 \mu \mathrm{g} / \mathrm{dl}$ (normal range 0.2-2.7). In the Pathology Department: in the morning (8:00 AM) mean serum cortisol values were $125 \pm$ $22 \mathrm{ng} / \mathrm{ml}$ and salivary cortisol values $2.1 \pm 1.1 \mu \mathrm{g} / \mathrm{dl}$ and at the end of the work (4:00 PM): mean serum cortisol values were $94.0 \pm 16.5 \mathrm{ng} / \mathrm{ml}$ and salivary cortisol values $1.22 \pm$ $0.2 \mu \mathrm{g} / \mathrm{dl}$. Mean weight of participants was $66.5 \mathrm{~kg} \pm 10 \mathrm{SD}$, mean BMI (body mass index) was $23.2 \mathrm{~kg} / \mathrm{m}^{2}$, mean blood pressure was $107 / 68 \mathrm{mmHg}$ and mean heart rate was $73 / \mathrm{min}$ \pm 5.8 SD. All the subjects had normal body temperature.

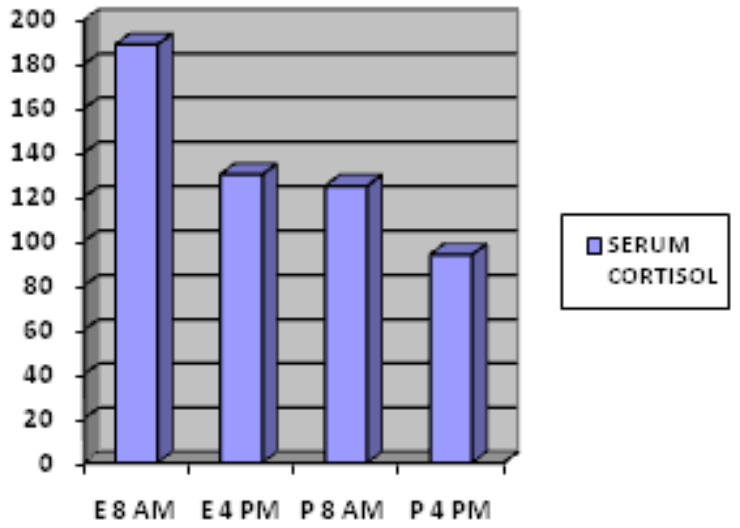

Graph 1: Mean serum cortisol values at emergency (E) and pathology $(\mathrm{P})$ department.

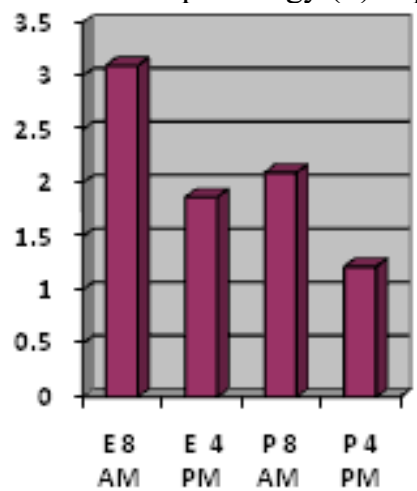

口5alivary Cortisol

Graph 2: Mean salivary cortisol values at emergency (E) and pathology $(\mathrm{P})$ department.

Table 1: Mean salivary and serum cortisol values at emergency and pathology department.

\begin{tabular}{|c|c|c|c|c|}
\hline Department & $\begin{array}{c}\text { Mean Salivary cortisol } \\
\text { 08:00 AM (before } \\
\text { work) }\end{array}$ & $\begin{array}{c}\text { Mean Salivary } \\
\text { cortisol 04:00 PM } \\
\text { (after work) }\end{array}$ & $\begin{array}{c}\text { Mean Serum } \\
\text { cortisol 08:00 AM } \\
\text { (before work) }\end{array}$ & $\begin{array}{c}\text { Mean Serum } \\
\text { cortisol 04:00 PM } \\
\text { (after work) }\end{array}$ \\
\hline Emergency & $3.1 \pm 1.4 \mu \mathrm{g} / \mathrm{dl}$ & $1.87 \pm 0.5 \mu \mathrm{g} / \mathrm{dl}$ & $188 \pm 30 \mathrm{ngl} / \mathrm{ml}$ & $130 \pm 28 \mathrm{ng} / \mathrm{ml}$ \\
\hline Pathology & $2.1 \pm 1.1 \mu \mathrm{g} / \mathrm{dl}$ & $1.22 \pm 0.2 \mu \mathrm{g} / \mathrm{dl}$ & $125 \pm 22 \mathrm{ng} / \mathrm{ml}$ & $94.0 \pm 16.5 \mathrm{ng} / \mathrm{ml}$ \\
\hline P values & 0.2 & 0.19 & 0.93 & 0.2 \\
\hline
\end{tabular}

We found correlation between serum and salivary cortisol values at the beginning of the work and after finishing the work, at the emergency and pathology cortisol values, correlation coefficient $r=0.4$, and the values of salivary and serum cortisol values were higher at the emergency department compare to pathology department, but wasn't statistically significant (Table no 1).

Table 2: Mean salivary and serum cortisol values in females and males.

\begin{tabular}{|c|c|c|c|c|}
\hline Department & $\begin{array}{c}\text { Mean Salivary cortisol } \\
\text { 08:00 AM (before work) }\end{array}$ & $\begin{array}{c}\text { Mean Salivary cortisol } \\
\text { 04:00 PM (after work) }\end{array}$ & $\begin{array}{c}\text { Mean Serum cortisol } \\
\text { 08:00 AM (before work) }\end{array}$ & $\begin{array}{c}\text { Mean Serum cortisol } \\
\text { 04:00 PM (after work) }\end{array}$ \\
\hline Female & $2.5 \pm 1.9 \mu \mathrm{g} / \mathrm{dl}$ & $1.1 \pm 0.4 \mu \mathrm{g} / \mathrm{dl}$ & $141 \pm 58 \mathrm{ngl} / \mathrm{ml}$ & $81.3 \pm 29 \mathrm{ng} / \mathrm{ml}$ \\
\hline Males & $3.4 \pm 3.3 \mu \mathrm{g} / \mathrm{dl}$ & $1.69 \pm 0.7 \mu \mathrm{g} / \mathrm{dl}$ & $155 \pm 26 \mathrm{ng} / \mathrm{ml}$ & $114 \pm 27 \mathrm{ng} / \mathrm{ml}$ \\
\hline P values & 0.9 & 0.9 & 0.19 & 0.25 \\
\hline
\end{tabular}

The serum and salivary values of cortisol of males in our study were higher compared with females' values, but sex differences in salivary and serum cortisol values among nurses weren't statistically significant and we didn't found a correlation $(\mathrm{r}=-0.1 ; \mathrm{p}>0.05)$. 


\section{International Journal of Science and Research (IJSR) \\ ISSN (Online): 2319-7064}

Index Copernicus Value (2013): 6.14 | Impact Factor (2014): 5.611

\section{Discussions}

Previous studies have also indicated that cortisol levels differ between men and women [8]-[11], [12]-[14]. In our study, there were noticed higher levels of salivary and serum cortisol values in the nurses working in the emergency department, compared to the nurses working in the pathology department. But our study had some limitations: first, the number of participants, which was small and we needed to perform the study in a bigger group of nurses, to have more trustful conclusions; second, we know that in the emergency department the work is more intensive and there is the need to work quickly, but we did not use any indicator to measure the level of stress at the nurses in both groups, the emergency and the pathology department.

\section{Conclusions}

Mean salivary and serum cortisol values were higher in males compare to females, but are not statistically significant. Since the stress of work is higher in the Emergency Department, even the results of the salivary cortisol values were higher in the nurses of the Emergency Department compared to the nurses of Pathology Department and there existed a correlation between salivary and serum values, which wasn't statistically significant $(p>0.05)$, but the study needed a bigger group of nurses to have more trustful conclusions.

\section{References}

[1] Hamrahian H Amir, Oseni Tawakalitu, Arafah M Baha, Measurements of Serum Free Cortisol in Critically Ill Patients. New Eng J Med 2004; 350: 1629-1638

[2] Arlt W \& Allolio B. Adrenal Insufficiency. Lancet 2003; 361: 1881-1893.

[3] Reynolds RM, Stewart PM, Seckl JR \& Padfield PL. Assessing the HPA axis in patient with pituitary disease: a UK survey. Clin Endocrinol (Oxf) 2006; 64(1): 82-85

[4] Neiman LK, Biller BM, Findling JW, Newell-Price J, Savage MO, Stewart PM \& Montori VM. The diagnosis of Cushing's syndrome: an Endocrine Society Clinical Guidelines. J Clin Endocrinol Metab 2008; 93 (6): 15261540.

[5] Elamin MB, Hassan Murad M, Mullan R, Erickson D, Harris K, Nadeem S, Ennis E, Erwin PJ \& Montori VM. J Clin Endocrinol Metab 2008; 93: 1553-1562.

[6] Deutschbein T, Broecker-Preuss M, Flitsch J, Jaeger A, Althoff R, Mann K, Petersenn S. Salivary cortisol as a diagnostic tool for Cushing's syndrome and adrenal insufficiency: improved screening by an automatic immunoassay. Eur J Endocrinol. 2012: 166 (4): 613618.

[7] Grade AH, Hansen AM. Long-term stability of salivary cortisol. Scand J Clin Lab Invest. 2005. 65 (5): 433-436.

[8] Van Cauter E, Leproult R, Kupfer DJ; Effects of gender and age on the levels and ciradian rhytmicity of plasma cortisol. J Clin Endocrinol Metab 1996. 81: 2468-2473.

[9] Seeman TE, Singer B, Wilkinson CW, McEwen B: Gender differences in age-related changes in HPA axis reactivity. Psychoneuroendocrinology 2001. 26: 225240.
[10] Kudielka BM, Buske-Kirschbaum A, Hellhammer DH, Kirschbaum C: HPA axis reponses to laboratory pschosocial stress in healthy elderly adults, younger adults, and children: impact of age and gender. Pschoneuroendorinology 2004. 29 (1): 83-98.

[11]Zha Z-Y, Lu F-H, Xie Y, Fu Y-R, Bogdan A, Touitou $\mathrm{Y}$ : Cortisol secretion in the elderly. Influence of age, sex and cardiovascular disease in the Chinese population. Steroids 2003. 68 (6): 551-555.

[12] Laughlin GA, Barret-Connor: Sexual dimorphism in the influence of advanced aging on adrenal hormones levels: The Rancho Bernardo Study. J Clin Endocrinol Metab 2008. 85 (10): 3561-3568.

[13] Gusenoff JA, Harman M, Veldhuis JD, St Clair C, Munzer T, Christmass C, O’Connor KG, Stevens TE, Bellantoni MF, Pabst K, Blackman MR. Cortisol and GH secretory dynamics, and their interrelationships, in healthy aged women and men. Am J Physiol Endocrinol Metab 2001. 280(4): E 661-E 625.

[14] Larsson A Ch, Gullberg Bo, Rastam L and Lindblad ULF. Salivary cortisol differs with age and sex and shows inverse associations with WHR in Swedish women: a cross-sectional study. BMC Endocrine Disorders 2009. 9:16.

\section{Author Profile}

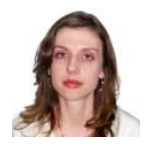

Blertina Dyrmishi (Corresponding author). Finished the study in Medicine University of Tirana, Albania in 2001. Graduated as Endocrinologist in 2007 in the Service of Endocrinology, University Hospital Center, Tirana, Albania. Actually work as Endocrinologist in the Internal Medicine Department, Hygeia Hospital Tirana, Albania. 